\title{
STUDIES ON ENVIRONMENT, HEALTH AND SAFETY (EHS) PRACTICES IN A SMALL SCALE AND LARGE SCALE INDIAN INDUSTRY
}

\author{
M.P.Manivannan', P. Raj Mohan ${ }^{2}$, P.S.S.Srinivasan ${ }^{3}$ \\ ${ }^{1}$ Knowledge Institute Of Technology, Anna University, Kakapalayam, Salem-637504, Tamilnadu, India \\ ${ }^{2}$ Knowledge Institute Of Technology, Anna University, Kakapalayam, Salem-637504, Tamilnadu, India \\ ${ }^{3}$ Knowledge Institute Of Technology, Anna University, Kakapalayam, Salem-637504, Tamilnadu, India
}

\begin{abstract}
With increase in the level of globalization, awareness of employees as well as industries on environment, health \& safety (EHS) issues are on the raise. The Indian industries are found to adopt the EHS norms specified by the regulatory authorities in India. The study involved a self-administered questionnaire among the workers and interviews with industry experts involved in environment, health and safety. The questionnaire concerned with the personal particulars and questions were based on human, machine and work environment factors of industry-accepted environment, health and safety (EHS) attributes. The industries in the study are large scale level and small scale level. The sample size was 120. The proposed research work aim to study the level of implementation of environment, health and safety norms in Indian industries; to study the reasons of slackness in implementation of the norms, to assess the impact of such poor implementation on employees moral, impact to the business, loss of life.
\end{abstract}

Keywords: EHS Practices, Large scale and Small scale industries, Influencing EHS attribute, Self- administered survey, Assessment $* * *$

\section{INTRODUCTION}

Economic development of a country is directly related to the level of industrial growth. The expansion of industrial sector leads to a greater utilization of natural resources, production of goods and services, creation of employment opportunities and improvement in the general standard of living. India has also been striving to develop the country's industrial base over since independence. It has framed various policies aimed at development of industries in the public and private sectors [22]. Companies that consider environmental protection, occupational health and safety at work as important as providing quality products usually have managers and departments responsible for these issues. They are called environmental, health and safety (EHS) departments, also SHE or HSE departments. EHS management has two general objectives: prevention of incidents or accidents that might result from abnormal operating conditions on the one hand and reduction of adverse effects that result from normal operating conditions on the other hand.

The present work was aimed at finding evidence of the EHS practices that were in place at the various Indian industries and at identifying both the strengths of that practices and any areas in which it could be improved. The score resulted from the analysis of those strengths and areas needed for improvement are identified. The identification of perceptions and evidence, the agreement on the strong points and areas for improvement and the quantification of the practices can been performed [15].

\subsection{History of EHS}

The first formal EHS management approach was introduced in 1985 by the chemical industry as a reaction to several catastrophic accidents (like the Seveso disaster and the Bhopal disaster). This worldwide voluntary initiative called "Responsible Care" is in place in about 50 countries and centrally coordinated by the International Council of Chemical Associations (ICCA). It involves eight fundamental features that ensure plant and product safety, occupational health and environmental protection but also try to demonstrate by image-building campaigns that the chemical industry acts in a responsible manner. Still, this initiative is restricted to the chemical industry. Since the 1990s, general approaches to EHS management that may fit any type of organization can be found in international standards like ISO 14001 for environmental management and OHSAS 18001 for occupational health and safety management or the European Eco-Management and Audit Scheme (EMAS). In 1998, EHS guidelines were also created by the International Finance Corporation.

\subsection{Environment, Health, Safety Practices and the}

\section{Law}

Regulatory requirements play an important role in both approaches and consequently, EHS department and managers must identify and understand relevant EHS regulations, the implications of which must be communicated to top management (the board of directors) so the company can 
implement suitable measures. Organizations based in the India are subject to EHS regulations and Indian labour laws. Indian labour law refers to laws regulating employment in India. There are over fifty national laws and many more state-level laws. Traditionally Indian governments at federal and state level have sought to ensure a high degree of protection for workers (allegedly). For instance, a permanent worker can be terminated only for proven misconduct or for habitual absence. Collective labour law: The Industrial Disputes Act (1947) requires companies employing more than 100 workers to seek government approval before they can fire employees or close down. In practice, permissions for firing employees are seldom granted. Trade Unions Act 1926 Provisions of the Factories Act, 1948. Individual labour law: All India Organisation of Employers points out that there are more than 55 central labour laws and over 100 state labour laws. The Contract Labour Act (1970) aims at regulating employment of contract labour so as to place it at par with labour employed directly. Women are now permitted to work night shifts too (10pm to 6am). Minimum Wages Act 1948, Weekly Holidays Act 1942, Beedi and Cigar Workers Act 1966, The Payment of Wages Act, 1936, The Workmen's Compensation Act, 1923, The Factories Act, 1948, The EPF Act, The Bonus Act, The ESI Act.

A study was presented on an empirical investigation of the influence of management system certification on the relationship between safety management and safety performance in major accident hazard chemical industry. They emphasized the need for OHSAS 18001 certification to reduce the accidents and thereby to reduce liability and improve productivity and safety and health of employees [25].

Systematic violations of legal requirements have repeatedly caused accidents at workplaces with certified management systems. Why employers introduce management systems can affect their implementation and outcomes. Internal objectives, of productivity and/or work-related health, require upstream prevention and a genuine influence by workers and their safety representatives [13].

\subsection{Environment Attributes}

Global human population and urban development are increasing at unprecedented rates and creating tremendous stress on local, regional, and global air and water quality [12].With passage of time, people realized that polluted air has serious effects on their health, climate and economics. Air pollution in India has been aggravated by a number of developments such as the growth in the size of cities, rapid economic development, industrialization and increasing traffic and levels of energy consumption. With respect to increase in industrial activities, population both endemic and floating and vehicular population, etc., have led to a number of environmental problems including air pollution (as cited in [2]) were reported [9] [4]. To minimize harm from contaminants, the control of air pollution through environmental policy is achieved through a combination of monitoring, modelling and emission control strategies [26].
Like air quality, the sources of water contamination can be either anthropogenic or natural. In some regions, natural geology or soils contain high background concentrations of phosphorus (e.g., Tualatin River in Oregon, USA, cited in [3]) and arsenic (e.g., India and Bangladesh cited in [23]), threatening human and ecosystem health. In many parts of the USA and Europe, surface waters are generally protected through the implementation of best management practices (BMPs). BMPs may be structural or non-structural, and are often applied at local (immediate proximity of development) or at the watershed scales [20]. By considering all the literature, applicable standards and environmental adverse impacts due to the industrial growth, measurement of the environment related implementation in industries are to be considered in the present study. The environment attributes framed in the study are emission sampling, stack emission, comply with standards, air quality survey, dust emission control, vehicle dust control, noise level, quality of water, trees variety, sewage units, RO plant, solid waste, treated effluent.

\subsection{Health Attributes}

Hazards associated with waste produced by healthcare establishments (HCEs), and the increased potential for infection and injury, have been frequently described [14] [10] [29] (as cited in [16]). It is now generally advocated in public health and education that, for a variety of reasons, qualitative, as well as quantitative, information be collected for the purpose of evaluating programs [8]. This recommendation has more recently been extended to safety research in particular [17]. Qualitative information can be gathered through interviews, observation and the use of primary and secondary documents [18] [7]. On the other hand, socially responsible management had active health and safety programs long before they were made mandatory by law. These aspects have paved the way for the health assessment in the industries. In the present study, the health related practices in the industries are measured by using the following attributes: cleanliness, painting, waste disposal, ventilation \& temperature, dust and fume, overcrowding, lighting, drinking water, latrines and urinals, health centre, medicines, medical Officer, health Records, medical examination and bio-medical waste.

\subsection{Safety Attributes}

A safety measure is the part of a facility, including any system, procedure, process or device that is intended to eliminate hazards, prevent the occurrence of incidental scenarios (prevention measures), reduce the severity of their consequences or limit effects (protection or mitigation measures). Safety measures can be regarded as the "barriers" between the hazards, the occurrence of a major accident and the harm that may be caused to people, property and the environment [28]. The employer should identify measures and understand how they actually control or affect hazards and risks. Each identified measure should be clearly linked to the hazard, initial cause, scenario or outcome it is designed to control [6] [21]. Then defined eight criteria (further broken down into 17 questions) for evaluating 
occupational safety intervention research [7]. By considering all the literature and the applicable standards (The Factories Act, 1948) related to safety, the safety attributes are framed in the study. Safety attributes includes eye protection, lightening protection, firefighting drills, training, material handling, electrical apparatus, storage of chemicals, cautionary notice, authorized persons, alarm systems, emergency procedure, MSDS.

Table 1: Elements of EHS attributes

\begin{tabular}{|c|c|c|c|}
\hline $\begin{array}{l}\text { Attributes } \\
\text { classification }\end{array}$ & $\begin{array}{l}\text { Environm } \\
\text { ent } \\
\text { attributes }\end{array}$ & $\begin{array}{l}\text { Health } \\
\text { attributes }\end{array}$ & $\begin{array}{l}\text { Safety } \\
\text { attributes }\end{array}$ \\
\hline $\begin{array}{l}\text { Attributes } \\
\text { elements }\end{array}$ & $\begin{array}{l}\text { emission } \\
\text { sampling } \\
\text { stack } \\
\text { emission } \\
\text { comply } \\
\text { with } \\
\text { standards } \\
\text { air quality } \\
\text { survey } \\
\text { dust } \\
\text { emission } \\
\text { control } \\
\text { vehicle } \\
\text { dust } \\
\text { control } \\
\text { noise level } \\
\text { quality of } \\
\text { water } \\
\text { trees } \\
\text { variety } \\
\text { sewage } \\
\text { units } \\
\text { RO plant } \\
\text { solid waste } \\
\text { treated } \\
\text { effluent }\end{array}$ & $\begin{array}{l}\text { cleanliness } \\
\text { painting } \\
\text { waste } \\
\text { disposal } \\
\text { ventilation } \\
\text { \& } \\
\text { temperatur } \\
\text { e } \\
\text { dust and } \\
\text { fume } \\
\text { overcrowdi } \\
\text { ng } \\
\text { lighting } \\
\text { drinking } \\
\text { water } \\
\text { latrines } \\
\text { and urinals } \\
\text { health } \\
\text { centre } \\
\text { medicines } \\
\text { medical } \\
\text { Officer } \\
\text { health } \\
\text { Records } \\
\text { medical } \\
\text { examinatio } \\
\mathrm{n} \\
\text { bio- } \\
\text { medical } \\
\text { waste }\end{array}$ & $\begin{array}{l}\text { eye } \\
\text { protection } \\
\text { lightening } \\
\text { protection } \\
\text { firefightin } \\
\text { g drills } \\
\text { training } \\
\text { material } \\
\text { handling } \\
\text { electrical } \\
\text { apparatus } \\
\text { storage of } \\
\text { chemicals } \\
\text { cautionary } \\
\text { notice } \\
\text { authorized } \\
\text { persons } \\
\text { alarm } \\
\text { systems } \\
\text { emergency } \\
\text { procedure } \\
\text { MSDS } \\
\text { permit to } \\
\text { work } \\
\text { system } \\
\text { intimation } \\
\text { of accident } \\
\text { PPE } \\
\text { safety } \\
\text { officer }\end{array}$ \\
\hline
\end{tabular}

\section{MATERIALS AND METHODS:}

HSE management would benefit greatly from guidance on how to use existing management systems efficiently and also from the further development of meaningful safety performance indicators that identify the conditions prior to accidents and incidents are shown. [5] [1].

The projects involved in the industries of both large scale and small scale industry. The group of workers comprised of all levels of employees associated with the industrial activity both in direct and in contract role. The questionnaires were designed based on the elements of the environment, health and safety attributes. They were designed to be simple and brief. They were checked by EHS department managers from various industries for suitability and completeness. Suggestions of industry experts on the language level, relevance and comprehensiveness of questions and the general approach of the survey were also incorporated. The materials for the study were records and reports and results of the questionnaires [27] [19].

The questionnaire was constructed in two parts; First part on personal particulars, years of experience, department, etc. and the second part attribute elements of environment, health and safety attributes as shown in attributes classification of Table 1. Questionnaire forms and verification interviews were then arranged and conducted during breaks and after shift periods.

The data is collected from the sample size of 120 from both the large scale and small scale industries. Table 2 shows the demographic data for respondents. First part of the questionnaire are straightforward and for second part respondents were requested to rate each of the questions on the environment, health and safety attribute elements on the three-point scale, varying from "zero" to "hundred". The distribution of the point score from the respondents for each safety element was computed to determine the mode for each factor. The mode for each element was further strengthened by examining the maximum, the minimum, the mean and standard deviation and variance as the value for the strongest probable score value for the element. The most influential factor could then be determined by examining and comparing the overall scores for each factor [27].

Most of the employees of the industry have unstable or unfavorable work schedules. This made the conducting of interviews very difficult. Another limitation was the reluctance of the respondents in disclosing information with the view that the information will be disclosed to the outside world and it could be used against the industry.

Table 2: Demographic data for respondents

\begin{tabular}{|l|l|l|l|}
\hline Questions & $\begin{array}{l}\text { Classificatio } \\
\mathbf{n}\end{array}$ & $\begin{array}{l}\text { Large } \\
\text { scale } \\
\text { industry }\end{array}$ & $\begin{array}{l}\text { Small } \\
\text { scale } \\
\text { industry }\end{array}$ \\
\hline \multirow{3}{*}{ Gender } & Male & 60 & 50 \\
\cline { 2 - 4 } & Female & 0 & 10 \\
\hline \multirow{5}{*}{ Age } & $<20$ years & 4 & 6 \\
\cline { 2 - 4 } & $21-30$ & 42 & 36 \\
\cline { 2 - 4 } & $31-40$ & 10 & 14 \\
\cline { 2 - 4 } & $>40$ years & 4 & 4 \\
\hline Position & Top & 20 & 20 \\
\cline { 2 - 4 } & Middle & 20 & 20 \\
\cline { 2 - 4 } & Lower & 20 & 20 \\
\hline \multirow{3}{*}{ Department } & Safety & 5 & 0 \\
\cline { 2 - 4 } & Other & 55 & 60 \\
\hline \multirow{2}{*}{\begin{tabular}{l} 
Mode Employment \\
\cline { 2 - 4 }
\end{tabular}} & Employee & 50 & 40 \\
\cline { 2 - 4 } & Contract & 10 & 20 \\
\cline { 2 - 4 } & Sub- & 0 & 0 \\
\hline Total & Contract & 38 & 60 \\
\cline { 2 - 4 } Experience & $1-10$ & 22 & 0 \\
\hline
\end{tabular}




\section{RESULTS}

The results of implementation of the environment, health and safety practices in the large scale and small scale industry are presented.

\subsection{Large Scale Industry}

Every country needs exploring of coal, iron and steel, exploring of oil and its purification, heavy machineries, heavy electrical equipment, heavy chemicals, ships and aero planes, industries of heavy and basic industries for its development. All these industries help to develop agriculture, transport, communication facilities and other industries. It means development of large scale industries is almost essential for the development of heavy and basic industries. [11].

The large scale industry involved in the present study is located in urban centers and in the public sector and is run by big industrialists. Although the employees and management are exposed to higher levels of risk, they strictly abide the rules, regulation and laws because of their corporate requirement. The raw materials used are large and there is mass production; the work is done mostly by larger machines. Separate Environmental, Health and Safety (EHS) departments are formed to look after the issues and function of EHS practices in the industry. Managers, employees of EHS department will anticipate, prevent or eliminate risks and losses, monitor and evaluate performance of the employees, motivate safe behaviour among employees. Behaviour-based observations (e.g., safe or unsafe behaviours), near-miss incidents (e.g., incidents with serious injury or fatality potential), audits and training (e.g., EHS training for workers, managers, executives) are followed and hence continuous improvement towards the EHS practices shall be achieved.

The large scale industry issued all the requirements for the eye protection, warning signs installed in an area where danger from falling of objects on the eyes and radiation that may affects the human eyes. They handle mostly very heavy load. Hence they use mechanical handling equipment and procedures by using EOT cranes, gantry cranes, hoists, etc... Manual handling activities are less. Hence, the performance level of material handling can be further improved by following safe operating procedures, proper testing and inspections of the machines as per the standards, ensuring proper awareness and training for the operators of the material handling equipment.

They consider environmental protection, occupational health and safety at work as important as providing quality products. Hence in overall, the implementation level of environment, health and safety attributes were $87.07 \%, 90 \%$ and $90.93 \%$ respectively as shown in Figure 1, Figure 2, Figure 3 and Table 3.

\subsection{Small Scale Industry}

One of the largest weaknesses for small business owners is to raise finance. Small business owner has to bear high cost of production, which acts as one of the weakness for the small businesses. [24]. In the present study small scale industries employ less number of persons (45 direct role and 35 in contract role) and less annual turnover (80 Lakhs) while compared with the large scale industries as shown in Table 6 and in Table 7. Hence they refuse to spend more money in the EHS practices and issues.

Table 3: Overall implementation of EHS attributes

\begin{tabular}{|l|l|l|l|}
\hline $\begin{array}{l}\text { Industry } \\
\text { type }\end{array}$ & $\begin{array}{l}\text { Environm } \\
\text { ent } \\
\text { attributes } \\
\text { implemen } \\
\text { tation } \\
\text { level }(\%)\end{array}$ & $\begin{array}{l}\text { Health } \\
\text { attributes } \\
\text { implemen } \\
\text { tation } \\
\text { level }(\%)\end{array}$ & $\begin{array}{l}\text { Safety } \\
\text { attributes } \\
\text { implemen } \\
\text { tation } \\
\text { level (\%) }\end{array}$ \\
\hline Large scale & 87.07 & 90 & 90.93 \\
\hline Small scale & 71.16 & 61.93 & 54.68 \\
\hline
\end{tabular}

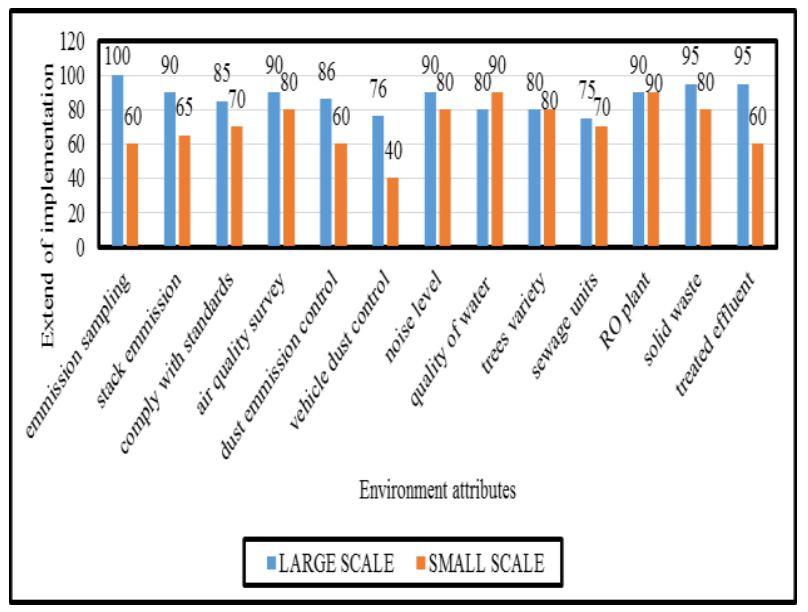

Fig 1: Implementation level of environment attributes in industries

In the environmental attributes implementation, the small scale industry implemented to an average level ranges between $60 \%$ to $70 \%$ for the emission sampling, stack emission, comply with standards, dust emission control, treated effluent because the activities concerned with these attributes are very less usage and followed to a minimum extent. But they follow all the activities related to surveying and recording of the air and water samples continuously as mentioned by the regulatory authorities of India because they need not to spend a lot of money in these activities. Hence the implementation level of these attributes like air quality survey, noise level, quality of water, trees variety, RO plant, solid waste are high in this small scale industry with a level of $80 \%$ to $90 \%$. The vehicle dust control is the least implementation level of $40 \%$ as they need not handle or work with more number of earth moving equipment like dozers, crawlers, mobile crane, etc.

In health related activities, they have lack of planning. This is best illustrated in which were found to segregate waste, but then allowed it to be remixed with general waste. This 
indicated a willingness to allocate some resources to proper waste management, but that the understanding required to follow this through to an effective final safe disposal was lacking.

Hence the implementation level of cleanliness, painting, and waste disposal ranges from $70 \%$ to $80 \%$. The proper planning can improve these factors even more. The implementation level of health centre, medicines, medical Officer, health Records, medical examination, bio-medical waste was $60 \%$, $40 \%, 0,30 \%, 60 \%, 0$ respectively. The main reason was due to the absence of the factory medical officer and separate occupational health centre inside the industry.

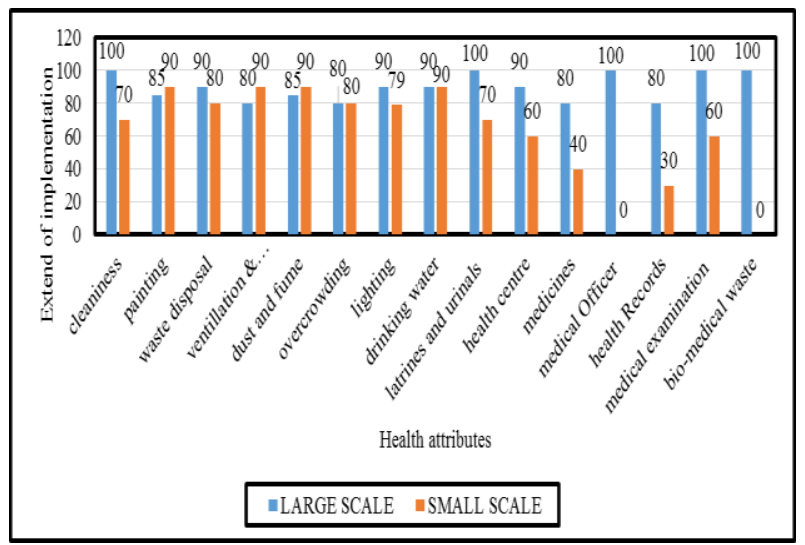

Fig 2: Implementation level of health attributes in industries

Absence of skilled personnel most of small scale businesses does not have skilled personnel. Due to which these businesses lack in identification of industrial projects for development, consultancy and counselling services, industrial training and skill formation [24]. Skilled labour is very essential for every industry. In the small scale industry involved in the present study, the firefighting drills, training and MSDS attributes are implemented due to the absence of skilled labour. Hence, more skilled labour should be appointed to improve these deficiencies.

The employer has responsibility to protect the employees from all health hazards that may pose threat to their safety and health. Safety hazards are those aspects of the work environment that have the potential of immediate and sometimes violent harm to an employee; for example loss of hearing, eyesight or body parts, arts, sprains, brushes, bruises, broken bones, burns and electric shock. The implementation level of the eye protection in this small scale industry is eye protection, lightening protection, material handling, electrical apparatus, and storage of chemicals ranges from $50 \%$ to $70 \%$. The employers should take necessary actions to improve these safety attributes implementation in the industry.

Small businesses do not use Information technology and its applications such as the designing of prototype machines for product identified according to country resources and requirements [24]. Hence they have very less updating of recent techniques, instruments, tool, tactics and machineries.
They follow an age old techniques for material handling, storage of chemicals, emergency procedure.

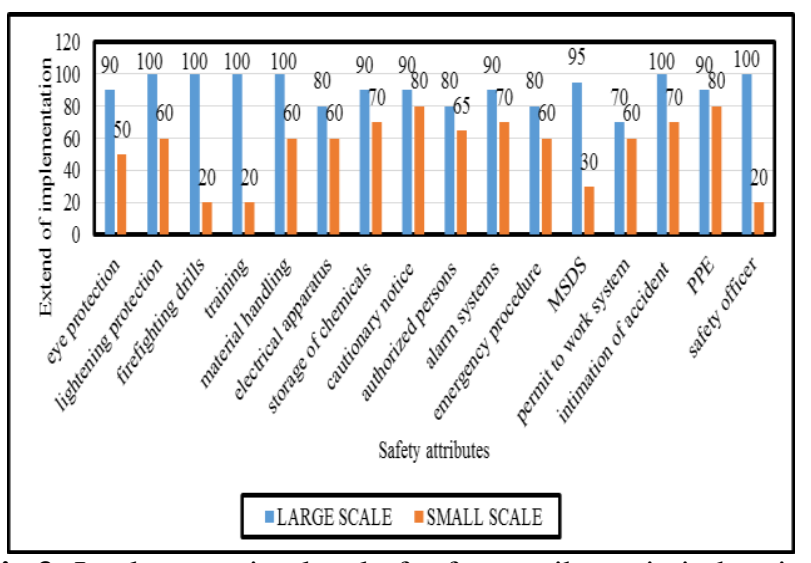

Fig 3: Implementation level of safety attributes in industries

Other weakness is to obtain the permission of and license from, the Industrial Development of the state, local bodies etc. But despite the policy of Government, petty officials are often unhelpful. A lot of time and energy is wasted in persuading these officials to perform their duties [24]. Hence in overall, the implementation level of environment, health and safety attributes of small scale industry were $71.15 \%$, $61.93 \%$ and $54.68 \%$ respectively as shown in Table 3.

\section{DISCUSSION}

For the discussion of results, the industries in the study are then classified into large scale and small scale industry based on the number of employees and the annual turnover of the company as given in Table 4 and Table 5.

Table 4: Number of employees according to the industry wise

\begin{tabular}{|l|l|l|}
\hline \multirow{2}{*}{ Responding industry } & \multicolumn{2}{|l|}{ Number of employees } \\
\cline { 2 - 3 } & Direct role & Contract role \\
\hline Large scale industry & 400 & 150 \\
\hline Small scale industry & 45 & 35 \\
\hline
\end{tabular}

Table 5: Annual turnover according to the industry wise

\begin{tabular}{|l|l|}
\hline Responding industry & Total (approximately) (Rs.) \\
\hline Large scale industry & 400 Crores \\
\hline Small scale industry & 80 Lakhs \\
\hline
\end{tabular}

In this current study it was found that among the influencing cluster of attributes determining the success of environment the most influential was the solid waste element; and among the health making up this cluster the prominent factor was painting and dust \& fumes and in safety was the cautionary notice, intimation of the accident and PPE. The statistics of the total environment, health and safety attribute scores listed in the Table 5, Table 6 and Table 7 indicates the minimum, the maximum, the mean, the standard deviation and the variance. They are all concerned with the need of management to get their employees more knowledgeable and informed about environment, health and safety issues. Better design and application of equipment and personal protective equipment (PPE) could contribute to higher quality of work. 
Employers could also consider reducing manual work for future improvements in the safety and health of their employees. Awareness on the right use of equipment or tools and wearing the PPE correctly could reduce risks [27].

Table 6: Statistics of results for environment attributes

\begin{tabular}{|l|l|l|l|l|l|l|l|}
\hline $\begin{array}{l}\text { Environm } \\
\text { ent } \\
\text { attributes } \\
\text { ge } \\
\text { scal } \\
\text { e }\end{array}$ & $\begin{array}{l}\text { Sma } \\
\text { scal } \\
\text { e }\end{array}$ & $\begin{array}{l}\text { Mi } \\
\mathrm{n}\end{array}$ & $\begin{array}{l}\text { Ma } \\
\mathrm{x}\end{array}$ & $\begin{array}{l}\text { Mea } \\
\mathrm{n}\end{array}$ & S.D. & $\begin{array}{l}\text { Varian } \\
\text { ce }\end{array}$ \\
\hline $\begin{array}{l}\text { emission } \\
\text { sampling }\end{array}$ & 100 & 60 & 60 & $\begin{array}{l}10 \\
0\end{array}$ & 80 & $\begin{array}{l}28.2 \\
8\end{array}$ & 800 \\
\hline $\begin{array}{l}\text { stack } \\
\text { emission }\end{array}$ & 90 & 65 & 65 & 90 & 77.5 & $\begin{array}{l}17.6 \\
7\end{array}$ & 312.5 \\
\hline $\begin{array}{l}\text { comply } \\
\text { with } \\
\text { standards }\end{array}$ & 85 & 70 & 70 & 85 & 77.5 & $\begin{array}{l}10.6 \\
0\end{array}$ & 112.5 \\
\hline $\begin{array}{l}\text { air quality } \\
\text { survey }\end{array}$ & 90 & 80 & 80 & 90 & 85 & 7.07 & 50 \\
\hline $\begin{array}{l}\text { dust } \\
\text { emission } \\
\text { control }\end{array}$ & 86 & 60 & 60 & 86 & 73 & 18.3 & 338 \\
\hline $\begin{array}{l}\text { vehicle } \\
\text { dust } \\
\text { control }\end{array}$ & 76 & 40 & 40 & 76 & 58 & 25.4 & 648 \\
\hline $\begin{array}{l}\text { noise } \\
\text { level }\end{array}$ & 90 & 80 & 80 & 90 & 85 & 7.07 & 50 \\
\hline $\begin{array}{l}\text { quality of } \\
\text { water }\end{array}$ & 80 & 90 & 80 & 90 & 85 & 7.07 & 50 \\
\hline $\begin{array}{l}\text { trees } \\
\text { variety }\end{array}$ & 80 & 80 & 80 & 80 & 80 & 0 & 0 \\
\hline $\begin{array}{l}\text { sewage } \\
\text { units }\end{array}$ & 75 & 70 & 70 & 75 & 72.5 & 3.53 & 12.5 \\
\hline RO plant & 90 & 90 & 90 & 90 & 90 & 0 & 0 \\
\hline $\begin{array}{l}\text { solid } \\
\text { waste }\end{array}$ & 95 & 80 & 80 & 95 & 87.5 & 10.6 & 112.5 \\
\hline $\begin{array}{l}\text { treated } \\
\text { effluent }\end{array}$ & 95 & 60 & 60 & 95 & 77.5 & 24.7 & 612.5 \\
\hline
\end{tabular}

Table 7: Statistics of results for health attributes

\begin{tabular}{|l|l|l|l|l|l|l|l|l|}
\hline $\begin{array}{l}\text { Health } \\
\text { attributes }\end{array}$ & $\begin{array}{l}\text { Lar } \\
\text { ge } \\
\text { scal } \\
\text { e }\end{array}$ & $\begin{array}{l}\text { Sm } \\
\text { all } \\
\text { scal } \\
\text { e }\end{array}$ & $\begin{array}{l}\text { Mi } \\
\text { n }\end{array}$ & $\begin{array}{l}\text { Ma } \\
\text { x }\end{array}$ & $\begin{array}{l}\text { Me } \\
\text { an }\end{array}$ & $\begin{array}{l}\text { S.D } \\
\cdot\end{array}$ & $\begin{array}{l}\text { Varia } \\
\text { nce }\end{array}$ \\
\hline $\begin{array}{l}\text { cleanines } \\
\text { s }\end{array}$ & 100 & 70 & 70 & $\begin{array}{l}10 \\
0\end{array}$ & 85 & $\begin{array}{l}21 . \\
21\end{array}$ & 450 \\
\hline painting & 85 & 90 & 85 & 90 & $\begin{array}{l}87 . \\
5\end{array}$ & $\begin{array}{l}3.5 \\
3\end{array}$ & 12.5 \\
\hline $\begin{array}{l}\text { waste } \\
\text { disposal }\end{array}$ & 90 & 80 & 80 & 90 & 85 & $\begin{array}{l}7.0 \\
7\end{array}$ & 50 \\
\hline $\begin{array}{l}\text { ventillatio } \\
\text { n \& } \\
\text { temperatu } \\
\text { re }\end{array}$ & 80 & 90 & 80 & 90 & 85 & $\begin{array}{l}7.0 \\
7\end{array}$ & 50 \\
\hline $\begin{array}{l}\text { dust and } \\
\text { fume }\end{array}$ & 85 & 90 & 85 & 90 & $\begin{array}{l}87 . \\
5\end{array}$ & $\begin{array}{l}3.5 \\
3\end{array}$ & 12.5 \\
\hline $\begin{array}{l}\text { overcrow } \\
\text { ding }\end{array}$ & 80 & 80 & 80 & 80 & 80 & 0 & 0 \\
\hline lighting & 90 & 79 & 79 & 90 & 84. & 7.7 & 60.5 \\
\hline
\end{tabular}

\begin{tabular}{|l|l|l|l|l|l|l|l|l|}
\hline & & & & & & 5 & 7 & \\
\hline $\begin{array}{l}\text { drinking } \\
\text { water }\end{array}$ & 90 & 90 & 90 & 90 & 90 & 0 & 0 \\
\hline $\begin{array}{l}\text { latrines } \\
\text { and } \\
\text { urinals }\end{array}$ & 100 & 70 & 70 & $\begin{array}{l}10 \\
0\end{array}$ & 85 & $\begin{array}{l}21 . \\
21\end{array}$ & 450 \\
\hline $\begin{array}{l}\text { health } \\
\text { centre }\end{array}$ & 90 & 60 & 60 & 90 & 75 & $\begin{array}{l}21 . \\
21\end{array}$ & 450 \\
\hline $\begin{array}{l}\text { medicines } \\
\text { medical }\end{array}$ & 80 & 40 & 40 & 80 & 60 & $\begin{array}{l}28 . \\
28\end{array}$ & 800 \\
\hline $\begin{array}{l}\text { Officer } \\
\text { health } \\
\text { Records }\end{array}$ & 80 & 30 & 30 & 80 & 55 & $\begin{array}{l}35 . \\
35\end{array}$ & 1250 \\
\hline $\begin{array}{l}\text { medical } \\
\text { examinati } \\
\text { on }\end{array}$ & 100 & 60 & 60 & $\begin{array}{l}10 \\
71\end{array}$ & 80 & $\begin{array}{l}28 . \\
28\end{array}$ & 800 \\
\hline $\begin{array}{l}\text { bio- } \\
\text { medical } \\
\text { waste }\end{array}$ & 100 & 0 & 0 & 10 & 50 & $\begin{array}{l}70 . \\
71\end{array}$ & 5000 \\
\hline
\end{tabular}

Table 8: Statistics of results for safety attributes

\begin{tabular}{|c|c|c|c|c|c|c|c|}
\hline $\begin{array}{l}\text { Safety } \\
\text { attributes }\end{array}$ & $\begin{array}{l}\text { Larg } \\
\mathrm{e} \\
\text { scal } \\
\mathrm{e}\end{array}$ & $\begin{array}{l}\text { Sma } \\
\text { ll } \\
\text { scal } \\
\mathrm{e}\end{array}$ & $\begin{array}{l}\mathrm{Mi} \\
\mathrm{n}\end{array}$ & $\begin{array}{l}\mathrm{Ma} \\
\mathrm{x}\end{array}$ & $\begin{array}{l}\text { Mea } \\
\mathrm{n}\end{array}$ & S.D. & $\begin{array}{l}\text { Varian } \\
\text { ce }\end{array}$ \\
\hline $\begin{array}{l}\text { eye } \\
\text { protectio } \\
n\end{array}$ & 90 & 50 & 50 & 90 & 70 & $\begin{array}{l}28.2 \\
8\end{array}$ & 800 \\
\hline $\begin{array}{l}\text { lightenin } \\
\mathrm{g} \\
\text { protectio } \\
\mathrm{n}\end{array}$ & 100 & 60 & 60 & 100 & 80 & $\begin{array}{l}28.2 \\
8\end{array}$ & 800 \\
\hline $\begin{array}{l}\text { firefighti } \\
\text { ng drills }\end{array}$ & 100 & 20 & 20 & 100 & 60 & $\begin{array}{l}56.5 \\
6 \\
\end{array}$ & 3200 \\
\hline training & 100 & 20 & 20 & 100 & 60 & $\begin{array}{l}56.5 \\
6 \\
\end{array}$ & 3200 \\
\hline $\begin{array}{l}\text { material } \\
\text { handling }\end{array}$ & 100 & 60 & 60 & 100 & 80 & $\begin{array}{l}28.2 \\
8 \\
\end{array}$ & 800 \\
\hline $\begin{array}{l}\text { electrical } \\
\text { apparatu } \\
\text { s }\end{array}$ & 80 & 60 & 60 & 80 & 70 & $\begin{array}{l}14.1 \\
4\end{array}$ & 200 \\
\hline $\begin{array}{l}\text { storage } \\
\text { of } \\
\text { chemical } \\
\text { s }\end{array}$ & 90 & 70 & 70 & 90 & 80 & $\begin{array}{l}14.1 \\
4\end{array}$ & 200 \\
\hline $\begin{array}{l}\text { cautionar } \\
\text { y notice }\end{array}$ & 90 & 80 & 80 & 90 & 85 & 7.07 & 50 \\
\hline $\begin{array}{l}\text { authorize } \\
\text { d } \\
\text { persons }\end{array}$ & 80 & 65 & 65 & 80 & 72.5 & $\begin{array}{l}10.6 \\
0\end{array}$ & 112.5 \\
\hline $\begin{array}{l}\text { alarm } \\
\text { systems }\end{array}$ & 90 & 70 & 70 & 90 & 80 & $\begin{array}{l}14.1 \\
4\end{array}$ & 200 \\
\hline $\begin{array}{l}\text { emergen } \\
\text { cy } \\
\text { procedur } \\
\text { e }\end{array}$ & 80 & 60 & 60 & 80 & 70 & $\begin{array}{l}14.1 \\
4\end{array}$ & 200 \\
\hline MSDS & 95 & 30 & 30 & 95 & 62.5 & $\begin{array}{l}45.9 \\
6 \\
\end{array}$ & 2112.5 \\
\hline
\end{tabular}




\begin{tabular}{|c|c|c|c|c|c|c|c|}
\hline $\begin{array}{l}\text { permit to } \\
\text { work } \\
\text { system }\end{array}$ & 70 & 60 & 60 & 70 & 65 & 7.07 & 50 \\
\hline $\begin{array}{l}\text { intimatio } \\
n \quad \text { of } \\
\text { accident }\end{array}$ & 100 & 70 & 70 & 100 & 85 & $\begin{array}{l}21.2 \\
1\end{array}$ & 450 \\
\hline PPE & 90 & 80 & 80 & 90 & 85 & 7.07 & 50 \\
\hline $\begin{array}{l}\text { safety } \\
\text { officer }\end{array}$ & 100 & 20 & 20 & 100 & 60 & $\begin{array}{l}56.5 \\
6\end{array}$ & 3200 \\
\hline
\end{tabular}

\section{CONCLUSIONS}

The results of this study demonstrate the assessing of the environment, health and safety practices of large and small scale Indian industries. With the use of the methodology, several objectives achieved are:

- Getting the EHS staffs of various industries involved in the assessment.

- The self-assessment of the EHS practices by getting evidence, strong points and areas for improvement in the implementation of practices.

- Categorization of the industries based on their implementation of EHS practices.

- The identification of the areas in which the industry can take corrective and preventive actions in order to strengthen its safety practices.

The result identifies and understands management deficiencies that contribute to EHS practice compliance, implementation level. The results can be used for developing and improving Safety Compliance Assurance Programs. Every industry can achieve zero illnesses and injuries, eliminate adverse environmental impacts, and contribute positively to the communities in which they operate by championing safe behaviours and environmentally sound practices. An effective and efficient implementation of the safety practices will translate into the overall effectiveness and efficiency of the organization.

\section{ACKNOWLEDGEMENTS}

This project was supported by the "EHS department" in various Indian industries. The authors extend particular thanks to the administration and EHS staffs in the company participated in the study. We thank for their support during the research study.

\section{REFERENCES}

[1] Azadeh, A., Rouzbahman, M., Saberi,M., Valianpour,F., \& Keramati, A. (2013). Improved prediction of mental workload versus HSE and ergonomics factors by an adaptive intelligent algorithm. Safety Science 58, 59-75.

[2] Bamniya, B.R., Kapoor, C.S., Smita Jain \& Kapoor, K. (2012). Impact Assessment of Air Pollution in Industrial Areas of Rajasmand and Udaipur Districts. Journal of Environmental Science, Computer Science and Engineering \& Technology; Vol.1.No.3, 411-417.
[7] Genevieve Baril-Gingras, Marie Bellemare, JeanPierre Brun, (2006). The contribution of qualitative analyses of occupational health and safety interventions: An example through a study of external advisory interventions, Safety Science 44 851-874.

[8] Green, L.W., \& Lewis, F.M., (1986). Measurement and Evaluation in Health Education and Health Promotion. May: Weld Publishing, Palo-Alto.

[9] Gupta, A.K., \& Sharma, S.K. (1994). Bioaccumulation of zinc in Cirrihinus; mrigala (Hamilton) fingerlings during short-term static bioassay. J. Environ. Biol., 15(3), 231-237.

[10] Hoyos, A., Cobo, M., Aristizabal, B., Cordoba, F., \& Correa, C.M., (2008). Total suspended particulate (TSP), polychlorinated dibenzodioxin (PCDD) and polychlorinated dibenzofuran (PCDF) emissions from medical waste incinerators in Antioquia, Colombia. Chemosphere 73, S137-S142.

[11] Jignesh H. Gadesha., \& Adhypak Sahayak, (2012). Research Expo International Multidisciplinary Research Journal: Volume - II, Issue - II June - 2012 ISSN: $2250-1630$.

[12] Jiunn Der Duha, Vivek Shandas, Heejun Changa, \& Linda A. Georgec, (2008). Rates of urbanisation and the resiliency of air and water quality. Science of the total environment 400 (2008) 238 - 256.

[13] Kaj Frick, (2011). Worker influence on voluntary OHS management systems - A review of its ends and means. Safety Science 49 974-987.

[14] Marinkovic, N., Vitale, K., Holcer, N.J., Dzakula, A., \& Pavic, T., (2008). Management of hazardous medical waste in Croatia. Waste Management 28, 1049-1056.

[15] Mariscal, M.A., Garcia Herrero, S., \& Toca Otero, A., (2012). Assessing safety culture in the Spanish nuclear industry through the use of working groups. Safety Science 50 (2012) 1237-1246.

[16] Masum A. Patwary, William Thomas O'Hare, \& Mosharraf H. Sarker, (2011). Assessment of occupational and environmental safety associated with medical waste disposal in developing countries: A qualitative approach. Safety Science 49, 1200-1207.

[17] Needleman, C., \& Needleman, M.L., (1996). Qualitative methods for intervention research: American Journal of Industrial Medicine 29, 329-337. 
[18] Patton, M.Q. (1990). Qualitative Evaluation and Research Methods, second ed. Sage Publications, Newbury Park, California, 532 p.

[19] Pornpimol Kongtip, Witaya Yoosook \& Suttinun Chantanakul., (2008). Occupational health and safety management in small and medium-sized enterprises: An overview of the situation in Thailand, Safety Science 46 (2008) 1356-1368.

[20] Schueler, T.R., \& Holland, H.K. (2000). The practice of watershed protection. Ellicott City, MD: Center for Watershed Protection.

[21] Shannon, H.S., Robson, L.S., \& Guastello, S.J., (1999). Methodological criteria for evaluating safety intervention research. Safety Science (31), 161-179.

[22] Sonia, \& Rajeev Kansal. (2009). Globalization and Its Impact on Small Scale Industries in India. PCMA Journal of Business. Vol. 1, No. 2 (June, 2009) pp. 135-146 ISSN 0974-9977.

[23] Spallholz, J.E., Boylan. L.M., \& Rhaman, M.M. (2004). Environmental hypothesis: is poor dietary selenium intake an underlying factor for arsenicosis and cancer in Bangladesh and West Bengal, India? Sci Total Environ 2004;323(1-3):21-32.

[24] Tanya Gupta, (2013). International Journal of Management and Social Sciences Research (IJMSSR): ISSN: 2319-4421 Volume 2, No. 1.

[25] Vinodkumar, M.N., \& Bhasi, M. (2011). A study on the impact of management system certification on safety management. Safety Science 49 498-507.

[26] Williams, M.L. (2008). Air quality risk management. J Toxicol Environ Health — Part A: Curr Issues;71:912.

[27] Zubaidah Ismail., Samad Doostdar., \& Zakaria Harun. (2012). Factors influencing the implementation of a safety management system for construction sites. Safety Science 50, 418-423. doi:10.1016/j.ssci.2011.10.001.

[28] Occupational Safety and Health Administration (OSHA), 1994. Hazard Identification, Risk Assessment and Control Measures for Major Hazard Facilities. Booklet 4.

[29] World Health Organization, (2004). Safe Healthcare Waste Management, Policy Paper. Department of Protection of the Human Environment Water, Sanitation and Health, 20 Avenue Appia, CH-1211, Geneva 27, Switzerland. 